\title{
A szintetikus kémiától az enzimmérnökségig - A Bioorganikus Kémiai Kutatócsoport bemutatása
}

\author{
POPPE László, NAGY József és HORNYÁNSZKY Gábor* \\ BME Szerves Kémia és Technológia Tanszék, Müegyetem rkp. 3, 1111 Budapest, Magyarország
}

\section{Bevezetés}

\subsection{Történelmi áttekintés}

A Szerves Kémia és Technológia Tanszék 2006-ben jött létre a Szerves Kémia Tanszék és a Szerves Kémiai Technológiai Tanszék egyesítésével. A két jogelőd tanszéket 1913-ban illetve 1938-ban alapították Zemplén Géza és Csürös Zoltán vezetésével, akik korábban hosszú ideig dolgoztak együtt. A Szerves Kémia Tanszék munkatársa volt a nemrég elhunyt nobel díjas kémikus Oláh György is. Zemplén Géza úttörő tevékenységét jól mutatja, hogy már 1915-ben - hazánkban elöször - nagysikerü könyvet írt az enzimekről.

A Bioorganikus Kémia Kutatócsoport 2005-ben alakult meg Dr. Poppe László egyetemi tanár vezetésével. A csoport munkáját jelenleg kettő senior kutató, egy posztdok ösztöndíjas, 11 doktoráns és közel 30 hallgató segíti. A Csoportban az elmúlt években 3 doktori fokozat, számos szakdolgozat és diplomamunka született, valamint további 4-5 kolléga doktori védése a közeljövőben várható.

\subsection{Kutatási háttér}

A Tanszéken $220 \mathrm{~m}^{2}$-es jól felszerelt laboratórium áll a Csoport rendelkezésére, mely magában foglalja úgy a szintetikus munkák végzésére szolgáló berendezéseket, mind az enzimekkel kapcsolatos teendők ellátására alkalmas készülékeket. A Csoport munkáját 2 HPLC, 3 GC, 3 UV-VIS spektrofotométer, centrifugák és az áramlásos kémia alkalmazására alkalmas eszközök segítik. Az enzimek modellezését megfelelő kapacitású számítógépeken tudjuk elvégezni a számításokhoz szükséges programcsomagok segítségével. Folyamatosan igyekszünk fejleszteni a rendelkezésre álló infrastruktúrát, különösen az enzimek testre szabásához szükséges berendezésekkel.

A Csoportunk jelenlegi tevékenységét számos korábbi kutatási projekt segítette elö. A 2008-2010 között lezajló FLOWREAC projektben a ThalesNano partnereként az áramlásos technológiák és az enzimrögzítési módszerek fejlesztése állt a figyelem középpontjában (NKFP 07 A2 FLOWREAC, NKTH). A projekt eredményeként mind folytonos reakciók, mind az enzimrögzítések területén komoly „knowhow”-ra sikerült szert tenni.
Nemzetközi együttmüködések is hozzájárultak az eredményességhez. A Babes-Bolyai Tudományegyetemen müködő, Dr. Paizs Csaba professzor által vezetett kutatócsoporttal végzett közös kutatómunka eredményeként számos nem természetes $\beta$-aminosav szintézise valósult meg szabad illetve különféleképen rögzített fenilalanin ammónia-liáz és fenilalanin 2,3-aminomutáz enzimek (közismert nevükön MIO-enzimek) segítségével (OTKA NN-103242 2012-2015 és PN-II-ID-PCE-2011-3-0799). 2016 végén Dr. Poppe László vezetésével indult meg Kolozsvárott a négy évre elnyert „Nanoscale Enzyme Immobilization and Microfluidics for Systems Biocatalysis" projekt (NEMSyB, ID P37_273, Cod MySMIS 103413). Dr. Poppe László professzor 2010-2012 között részt vett az EU COST (Actions „Cascade Chemoenzymatic Processes - New Synergies Between Chemistry and Biochemistry" CM 0701) projektjében, mely nagyban hozzájárult csoportunknak a biokatalízis terén meglévő tudása kiterjesztéséhez.

Az utóbbi években ipari szereplők partnereként két fontos KMR projektben is részt vettünk. Az „Új típusú, komplex kódolási eljáráson alapuló biztonsági, eredet- és egyediségjelölő hamisítás elleni rendszerek kifejlesztése" címü projektben (KMR 12-1-2012-0051, 2012-2015) a Pharmapress partnereként olyan anyagok kifejlesztésén dolgoztunk, melyeket folyékony vonalkódként lehet alkalmazni. Egy másik pályázat keretében a Fermentia Kft-vel közösen egy olyan berendezés kifejlesztésében vettünk részt, mely segítségével gyorsan és hatékonyan lehet rekombináns fehérjéket tisztítani. („Új hordozó család és automatizált módszerfejlesztő rendszer rekombináns fehérjék affinitás tisztítási technológiájának gyors kidolgozására”, KMR 12-1-2012-0140, 2013-2015.)

A molekulamodellezési kapacitásunk kiterjesztésében nagy segítségünkre volt a BME által elnyert TÁMOP pályázat („Új tehetséggondozó programok és kutatások a Müegyetem tudományos mühelyeiben", TÁMOP-4.2.2/B-10/1-2010-0009, 2011-2013), melynek keretében beszerzésre került egy szuperszámítógép. A nagyobb kapacitások kihasználásával lényegesen lerövidíthető a számításokra fordított gépidő.

Csoportunk szorosan együttmüködik Dr. Vértessy G. Beáta tanszékvezető egyetemi tanár kutatócsoportjával (Alkalmazott Biotechnológia és Élelmiszertudományi Tanszék) is a fehérjék kristályosítása és röntgenszerkezet-meghatározása területén. 


\section{Kutatási tevékenység}

A Bioorganikus Kémiai Kutatócsoport aktivitása széles tartományt ölel át. Az új szintetikus eljárások kidolgozásától kezdve, melyek során általában biokatalízist ${ }^{1}$ alkalmazunk sztereoszelektív szintézisekhez, ${ }^{2}$ a különböző enzimtisztítási és enzimrögzítési technikák kidolgozásán át, a szakaszos és folyamatos rendszerekben végzett enzim katalizálta reakciók vizsgálatán keresztül, ${ }^{3}$ a számításos kémia segítségével végzett enzimtervezésig. ${ }^{4,5}$ A csoportunk által leginkább tanulmányozott enzimek a lipázok és a MIO enzimeknek nevezett enzimcsaládok. Az utóbbi években az érdeklődésünket kiterjesztettük a ketoreduktázokra és a transzaminázokra is.

Az enzimek szerves makromolekulák, enyhe körülmények között müködnek, nagy enantiomerszelektivitással rendelkeznek és könnyen lebonthatóak, ezért környezetbarát anyagok. Hatásuk megegyezik a hagyományos katalizátorokéval. Azonban van néhány nehézség a használatukkal kapcsolatban. Az enzimek általában érzékenyek a külső körülményekre (hőmérséklet, $\mathrm{pH}$, oldószerek, stb.), az enzimgátlást kifejtő szennyezőkre, általában kis koncentrációjú oldatokban lehet velük dolgozni (gyenge a volumetrikus hozamuk), gyakran még drágábbak a hagyományos kémiai katalizátoroknál és előfordul, hogy müködésükhöz kofaktorra is szükség van. A fent említett nehézségek azonban nem leküzdhetetlenek. Megfelelő rögzítési módszerek alkalmazásával elérhetö, hogy az adott enzim tág müködési tartományban aktív maradjon, a folytonos technológiák alkalmazásával megnövelhető a volumetrikus hozam, a biotechnológia hihetetlen fejlődésének következtében pedig az enzimek elöállítási költségei lassan vetekednek a közönséges kémiai katalizátorokéval. (Különösen, ha figyelembe vesszük az egyre szigorodó környezetvédelmi elöírásokból adódó járulékos költségeket.) A rohamosan fejlődő számítástechnikai háttér segítségével egyre pontosabb képet kaphatunk az enzimek müködési mechanizmusairól, lehetővé válva ezáltal akár speciális, az adott szubsztrátra tervezett enzimek létrehozása.

\subsection{Enzimtisztítási és enzimrögzítési módszerek fejlesztése}

A Kutatócsoport fö érdeklődési területe új enzimrögzítési technikák kifejlesztése és azok alkalmazhatóságának vizsgálata kinetikus rezolválások és enentiotóp szelektív biotranszformációk során, különösen a folyamatos átfolyásos rendszerekben való alkalmazhatóság tekintetében (1. ábra). A már említett FLOWREAC projekt során rengeteg tapasztalatot szereztünk e témában, és a kutatásaink eredményeként, azóta is számos eredményt értünk el.

Az enzimek immobilizálása történhet szilárd hordozóhoz rögzítéssel, tárhálósítással illetve szerves vagy szervetlen polimer gélbe zárással. A fenti módszereken belül többfajta technikai megvalósítás létezik, illetve lehetséges az egyes módszerek kombinálása is (2. ábra).
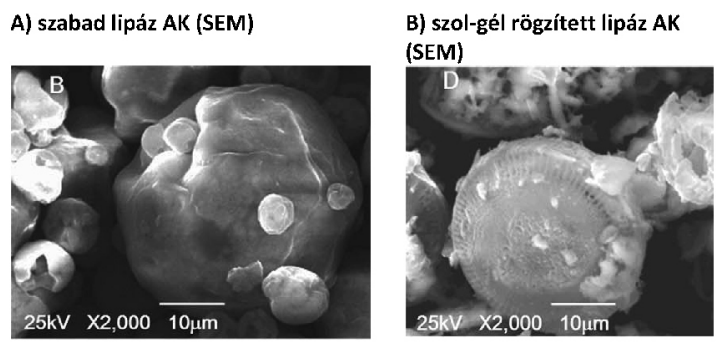

C) CatCart oszlopok és szol-gél rögzített lipázok

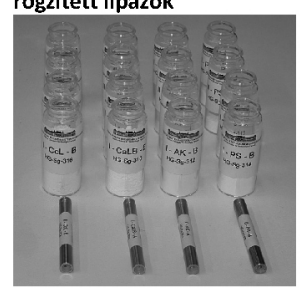

D) többoszlopos reaktor

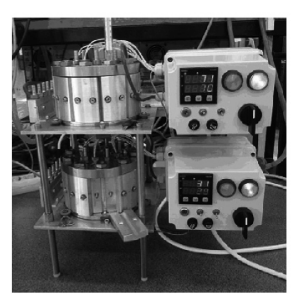

1. Ábra. Folyamatos átfolyásos reaktorokhoz használt enzimek (lipáz AK, lipáz PS, CcL, CaL B)

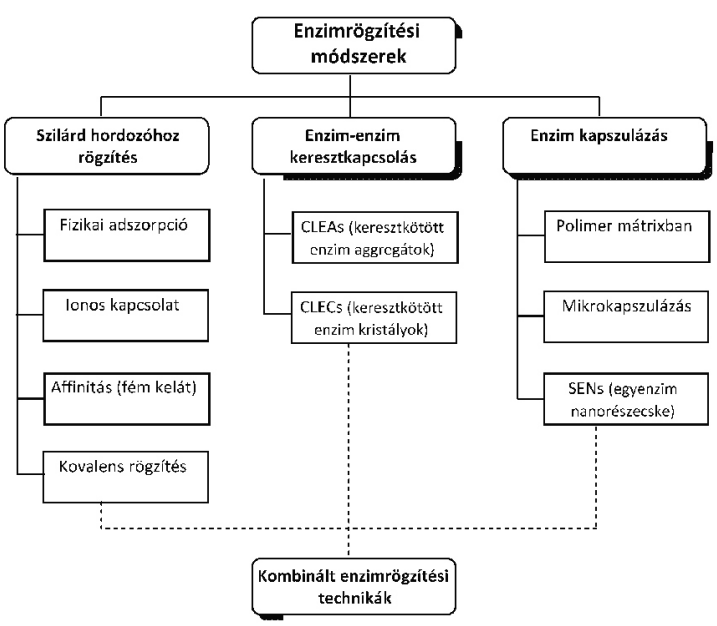

2. Ábra. Enzimrögzítési technikák bemutatása

Az enzimek szilárd hordozóhoz való rögzítése egyike azon eljárásoknak melyet az ipar is előszeretettel alkalmaz. A módszer előnye, hogy a katalizátor könnyen szeparálható a termékektől és általában megnövekszik általa az enzim hő és pH stabilitása, valamint a katalizátor újrafelhasználhatóvá is válhat. A különböző szerves és szervetlen hordozók közül a csoportunk a mezopórusos szilikagél hordozók vizsgálatára fókuszált. ${ }^{6-8}$ A szilikagél nagy fajlagos felülettel rendelkezik, relatív nagy pórusátmérője van (5-100 nm), ami megfelel az alkalmazott enzimek méretének. A felszín könnyen módosítható, ami lehetőséget nyújt a hordozó tulajdonságainak megváltoztatására. Lipázok esetén az adszorpciós rögzítés a leggyakrabban alkalmazott módszer, mert az eljárás nagyon egyszerű és nem igényli az enzimek módosítását. Ráadásul a felület módosításával kapott hordózók sikerrel alkalmazhatók az enzimszeparációs müveletekben is. ${ }^{6}$ A fenti eljárással készült, felületmódosított szilikagél hordozót sikerrel alkalmaztuk az 1-feniletanol kinetikus rezolválása során (3. ábra). Az aminoalkil funkciós csoportokat különböző biszepoxidokkal reagáltatva további variációs lehetőségek nyílnak meg. ${ }^{9}$ Számos felületmódosított szilikagél hordózót vizsgáltunk 
meg szisztematikusan a Candida antartica-ból (CaL A és CaL B), ${ }^{6}$ a Rhizomacor miehei-ből (RmL) és a Thermomyces lanuginosus-ból (TIL) ${ }^{7}$ származó lipázok rögzítésére hidrofób adszorpciós metodikát használva. A vizsgálatok eredményeként több új, különböző aktivitású és enantioszelektivitású biokatalizátor kifejlesztése történt meg. Sikerrel alkalmaztunk általunk kifejlesztett hordózókat Cal B enzim elválasztására másik lipáz enzim mellől, illetve a nyers fermentléböl is. Ezen tapasztalatok megerösítették, hogy a hidrofób adszorpciós technika hatékony és olcsó eljárás enzimek elválasztására is. A módszer használhatóságát bizonyítottuk azzal is, amikor a Pseudozyma aphidis-böl (PaL) származó lipáz enzimet rögzítettünk közvetlenül a fermentléből hatékony biokatalizátort nyerve egylépésben. ${ }^{6} \mathrm{Az}$ a tény, hogy az egyes enzimek esetében különböző módosítások szükségesek a hatékony biokatalizátorok elöállításához rámutatott, hogy a rögzítés optimális körülményei nem jósolhatóak meg előre.6,7 A legjobban teljesítő oktil- és fenil-módosított szilikagélekre rögzített Cal B enzimet átfolyásos rendszerekben is sikerrel alkalmaztuk. ${ }^{8}$

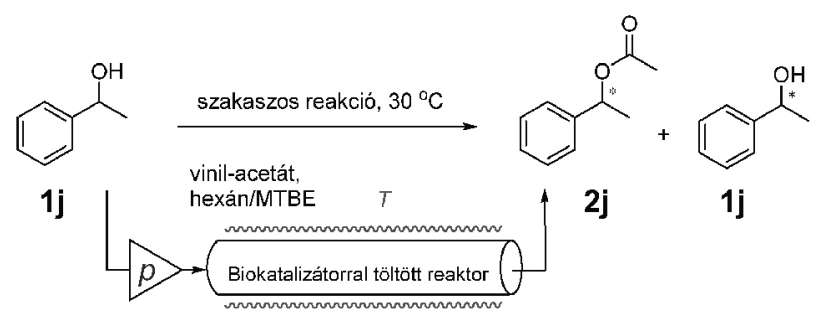

3. Ábra. 1-Feniletanol kinetikus rezolválása

Kutatócsoportunk összehasonlító vizsgálatokat végzett a hidrofób adszorpciós rögzítés és a kovalens rögzítés vonatkozásában. ${ }^{8}$ Ennek során megállapítottuk, hogy a CaL B enzim esetében a mezopórusos szilikagél ideális hordozó mindkét módszer viszonylatában. Számos amin kinetikus rezolválásának vizsgálata során megállapítottuk, hogy az optimális immobilizálási módszer függ, mind a szubsztrát természetétől, mind az alkalmazott reakciókörülményektől.

Lipázok szol-gél rögzítése is egyszerü és hatékony módja, hogy megnöveljük a biokatalizátor mechanikus stabilitását és katalitikus aktivitását. A rögzítés során az enzim megőrzi a szelektivitását, azonban a hőstabilitása és az aktivitása szignifikánsan növekszik. Csoportunk különböző körülmények között tesztelt számos szol-gél rögzített enzimet. ${ }^{10-14} \mathrm{~A}$ Pseudomonas flourescens-böl (Lipáz AK) származó Celit hordozós lipáz enzim szol-gél rögzitését vizsgáltuk alkiltrietoxiszilánt (alkil-TEOS), feniltrietoxiszilánt (PhTEOS) és tetraetoxiszilánt (TEOS) ${ }^{12}$ tartalmazó terner rendszerekben, és megállapítottuk, hogy legjobb eredményt az 1-feniletanol kinetikus rezolválásában a középhosszú láncot tartalmazó oktil-TEOS és perfluorooktil-TEOS tartalmú terner rendszerekkel érhetünk el. Dialkil-szubsztituált szilánok esetében azt találtuk, hogy a dimetildietoxiszilán (DMDEOS) használata mutatja a legjobb eredményt. ${ }^{14}$ Számos enzim esetében tanulmányoztuk a „bioimprinting jelenséget”, mely során szubsztrátszerü molekulát juttatunk az enzim aktív centrumába, melynek hatására az enzim felveszi az aktíy konformációját, és ebben az állapotában végezzük el a szol-gél rögzítést. Ezt követően a segédmolekulát eltávolítjuk a rendszerböl, viszont a rögzítés következtében az enzim az aktív konformációjában marad, megnövelve ezzel a kapott biokatalizátor aktivitását. ${ }^{13}$ A ,bioinprinting jelenséget” elektrospray technikával készített poli(vinil-alkohol) nanoszálban rögzített enzimekkel is tanulmányoztuk 8 különböző potenciális szubsztrátszerü anyagot tesztelve. ${ }^{15}$

Kutatócsoportunk elsőként mutatta be két különböző enzimcsalád esetében is, hogy az olcsó glicerindiglicidil-éter (GDE) előnyösen használható biszepoxid típusú keresztkötő ágensként térhálósított enzim aggregátumok (CLEAs) készítésekor. ${ }^{16}$ A GDE alkalmazásával lipáz CLEAs készítésekor számos lipáz enzim (Lipáz AK, Lipáz PS, CaL B) esetében mutattuk ki, hogy az jobb eredményeket szolgáltat, mint a megszokott glutáraldehid (GA) alkalmazása. A módszert sikeresen alkalmaztuk a Petroselium crispum-ból származó fenilalanin ammónia-liáz (PcPAL) esetében is (4. ábra).

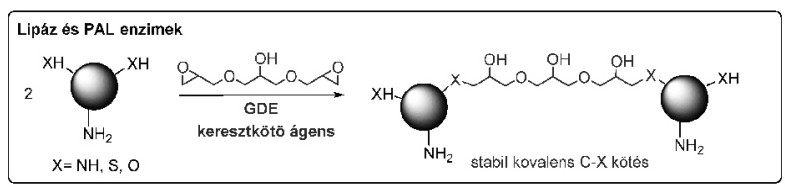

4. Ábra. Glicerin diglicidil éter (GDE) mint jól használható keresztkötő CLEA-k létrehozásához

\subsection{Kinetikus és dinamikus kinetikus rezolválások vizsgálata}

A királis intermedierek és finomvegyszerek nagyon fontos szerepet töltenek be a gyógyszeripar és a növényvédőszer gyártás folyamataiban. Számos multitonnás ipari folyamat használ enzimatikus kinetikus rezolválást, a legtöbb esetben lipázokat, melyek jól tolerálják a különböző szubsztrátokat. Ebből a megfontolásból fordult kutatócsoportunk is az enzim katalizálta kinetikus rezolválások (KR) és dinamikus kinetikus rezolválások (DKR) fejlesztése felé (5. ábra). Kinetikus rezolválás során azt használjuk ki, hogy a jelenlévő két enantiomer közül csak az egyik reagál. A kialakuló termékben pedig már két különböző vegyülettípus (pl.: alkohol és észter, vagy amin és savamid) lesz jelen, aminek elválasztása lényegesen egyszerübb. Azonban bármennyire is tökéletesen müködik a módszerünk 50\%-os konverziónál jobb átalakulást nem érhetünk el. Amennyiben sikerülne megoldani azt, hogy a visszamaradó enantiomer folyamatosan racemizáljon, abban az esetben akár a $100 \%$-os konverzió is elérhető. Ez esetben beszélünk dinamikus kinetikus rezolválásról. Az enzimek nagy szelektivitásuk miatt célszerü választásnak tünnek a KR és a DKR folyamatok katalizátorainak.

A különböző rezolválások tesztelése során elengedhetetlen, hogy gyors és hatékony elemzési módszer álljon rendelkezésre az adatok kiértékeléséhez. Ezért kutatócsoportunk kidolgozott egy enantiszelektív GC módszeren alapuló multi-szubsztrát elemző módszert lipáz enzimek által végzett kinetikus rezolválásokhoz. ${ }^{17}$ 
Az elmúlt években számos alkohol, amin és aminosav kinetikus rezolválását valósítottuk meg jó termeléssel és enantiomertisztasággal. Néhány példa a 6 . ábrán látható. ${ }^{16,18-22}$

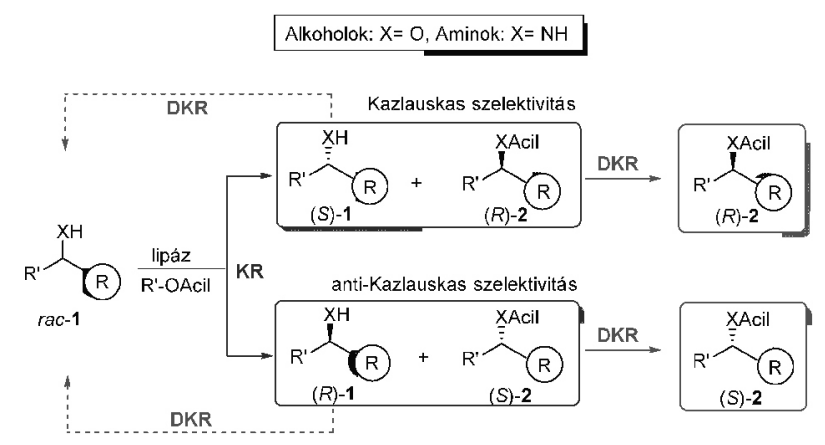

5. Ábra. Aminok és alkoholok kinetikus (KR) és dinamikus kinetikus (DKR) rezolválási lehetőségeinek bemutatása
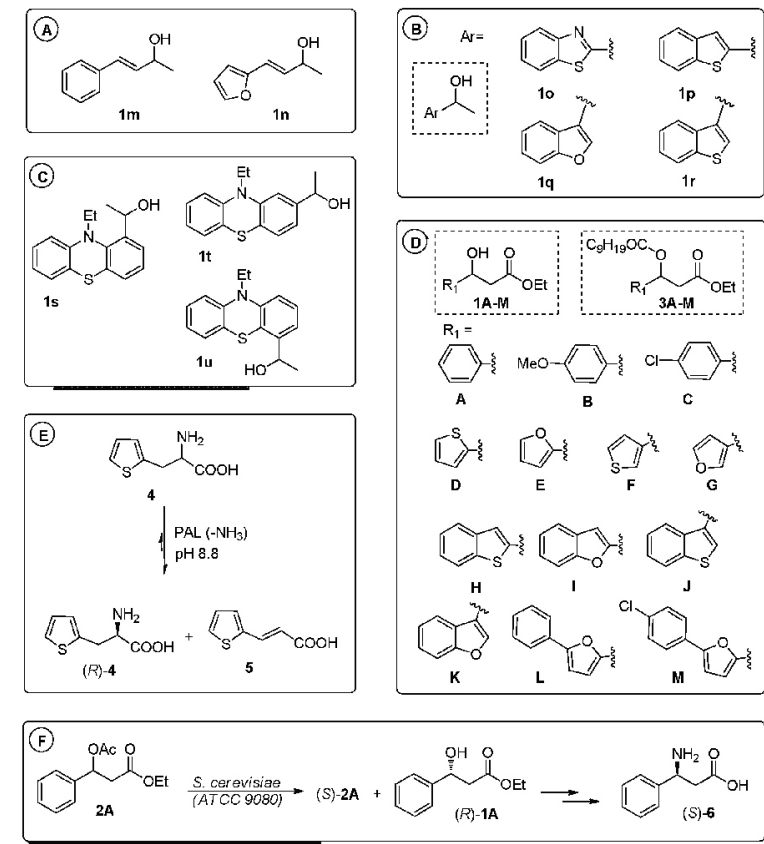

6. Ábra. Enzimkatalizált kinetikus rezolválások

Sikerrel alkalmaztuk a CaL B enzimet 1-feniletilamin kinetikus rezolválásában etil cianoacetátot használva acilezőszerként. Mindkét enantiomert sikerült nagy enantiomertisztaságban (ee $>98 \%$ ) elóállítni. (Az $(S)$ enantiomert a visszamaradó $(S)$ amin kémiai acilezése által nyertük.) Az enantiomerek felhasználásával tírozin kináz inhibitorokat állítottunk elö. ${ }^{23}$ Különbözőképpen rögzített $\mathrm{CaL} B$ enzimet vizsgáltunk ecetsav, 2-metoxiecetsav és 2-etoxiecetsav izopropil észtereivel végzett amidálási reakciókban. Megállapítottuk, hogy az izopropil észterek minden mutatóban felülmúlják az etil észterek teljesítményét, mind szakaszos, mind folytonos eljárások esetében. ${ }^{24}$

\subsection{Enantiotóp szelektív biotranszformációk}

Akirális szubsztrátok enantiotóp felületére történő addició során föként a termék egyik enantiomere keletkezik. Az etil 3-fenil-3-oxopropionát aszimmetrikus redukciója
Saccharomyces cerevisiae élesztőtörzs (ATCC 9080) segítségével tipikus példája ennek a biotranszformációnak (7A ábra). ${ }^{22}$ A GDE alapú PAL/BSA (szarvasmarha szérum albumin) társ-CLEA enzimrendszer aktív biokatalizátor sztereoszelektív ammónia addicióban. E katalizátorral az (E)-3-(tiofén-2-il)akrilsavból enatiospecifikusan keletkezik az (S)-2-amino-3-tiofén-2-il)propionsav (7B ábra). ${ }^{16} \mathrm{Ez}$ utóbbi reakciót szén nanocsövekre rögzített PAL enzimmel is tanulmányoztuk mind szakaszos módban, mind folytonos átfolyásos mikroreaktorban. A mikroreaktorban $60{ }^{\circ} \mathrm{C}$ felett 72 óra után sem tapasztaltuk az enzim aktivitásának csökkenését. $^{25}$
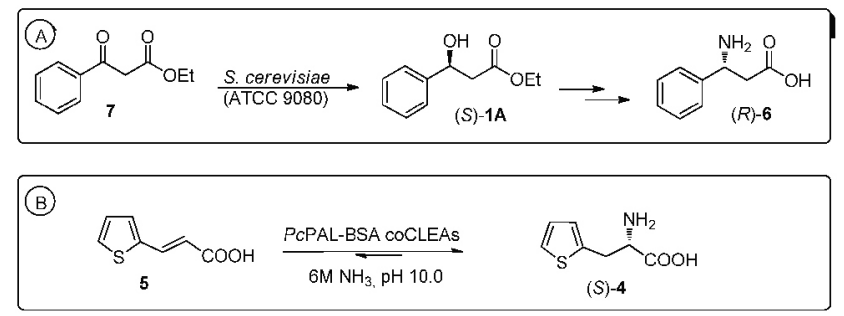

7. Ábra. Enantiotópszelektív biotranszformációk

Elsőként számoltunk be Wickerhamomyces subpelliculosus törzs egészsejtes biokatalizátorként való felhasználásáról prokirális ketonok sztereoszelektív redukciójában koszubsztrátként glükózt felhasználva. ${ }^{26}$

\subsection{Sztereoszelektív biotranszformációk átfolyásos reaktorokban}

A folytonos átfolyásos reaktorokban végzett reakciók nagy előnye, hogy egy adott időperiódusban viszonylag kis mennyiségü szubsztrát érintkezik nagy mennyiségü katalizátorral, ezáltal az átalakulás nagyon gyorsan megtörténik. A tartózkodási idő megfelelő megválasztásával a folyamat optimálható. Szerencsés esetben (100\%-os konverzió) a reaktorból kizárólag a termék lép ki. Megfelelően rögzített enzimet töltve a reaktorba sztereoszelektív folyamatok is végrehajthatók.

Prokirális diol aszimmetrikus acetilezését tanulmányoztuk folytonos átfolyásos töltött reaktorban szol-gél rögzített Lipáz PS katalizátor alkalmazásával (8A ábra). ${ }^{27}$ Vizsgáltuk a hőmérséklet $\left(0-60{ }^{\circ} \mathrm{C}\right)$ és az átfolyási sebesség $0,1-0,2$ $\mathrm{ml} /$ perc) hatását a konverzióra és az enentiomertisztaságra. Számos racém alkohol kinetikus rezolválását vizsgáltuk folytonos átfolyásos töltött reaktorban különböző lipáz katalizátorok alkalmazásával mind analitikai, mind preparatív léptékben (8B ábra). ${ }^{8,13,14,28,29}$ A folytonos és a szakaszos technológiák összehasonlító elemzése alapján megállapítható, hogy a folytonos technológiák minden esetben nagyobb produktivitást eredményeztek, miközben az enantiomertisztaság hasonló volt. ${ }^{28}$ Hasonló eredményekre vezettek a racém aminok körében végzett kinetikus rezolválások is ( $8 \mathrm{C}$ ábra). ${ }^{30,31}$ Különböző módon rögzített $\mathrm{CaL} B$ enzim katalitikus hatását vizsgáltuk átfolyásos reaktorban, és megállapítottuk, hogy a produktivitás és az enantiomertisztaság hőmérsékletfüggését mind a szubsztrát szerkezete, mind a rögzítés módja 
befolyásolja. A vizsgálatokhoz felhasznált racém aminokat egylépéses reduktív aminálással nyertük ketonokból. A reakciókat elvégeztük szakaszos és folytonos rendszerben is (8D ábra). ${ }^{32}$ Megállapítottuk, hogy az olcsó cinkpor a leghatékonyabb katalizátor a benzil helyzetű karbonil vegyületek esetében és a 10\%-os Pd/C katalizátor abban az esetben, ha a karbonil-csoport nincs konjugált rendszerben.
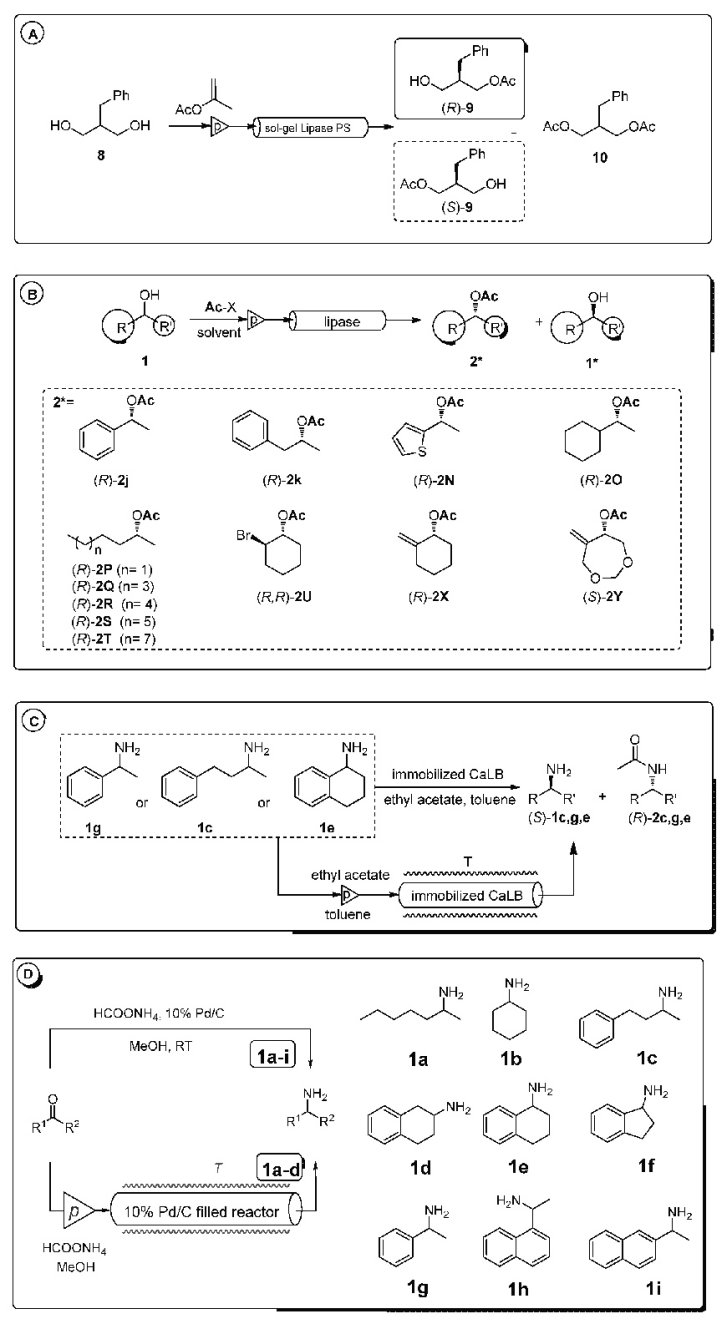

8. Ábra. Enzimkatalizált kinetikus reakciók folytonos átfolyásos reaktorban

2.5. Enzimek szerkezetének és hatásmechanizmusának tanulmányozása számításos kémia segítségével.

Kutatócsoportunkban a különböző enzimek kutatása során sikerrel alkalmaztuk az elméleti számításokat, úgy mint a homológia modellezést, a dokkolást, a molekuladinamikai és a QM/MM számításokat.

QM/MM módszerekkel vizsgáltuk a CaL B enzim müködését heteroaromás etanolok acilezési reakciójában. A számítások segítségével sikeresen megjósolható a keletkező észter abszolút konfigurációja. ${ }^{19}$
A MIO enzimek közé tartozó PcPAL enzim röngenszerkezetén alapuló részleges homológia modellezése során sikerült megszerkeszteni az alapvetően meghatározó tirozin tartalmú hurok katalitikusan aktív állapotú konformációját, és megállapítottuk, hogy a vizsgált röntgenszerkezetben az enzim inaktív állapotban van. Molekuladinamikai számítások segítségével felállítottunk egy hipotézist a C-terminális multihélix régiónak a tirozin-hurokra gyakorolt modulációs szerepére. ${ }^{33}$ A Rubrobacter xylanophilus törzsböl származó, extrém magas $\mathrm{pH}$ optimummal rendelkező RxPAL tulajdonságait alátámasztó magyarázatot adtunk homológia modellezés segítségével, lehetséges diszulfid hidak, kiterjedt sóhíd formációk és megemelkedett felszíni negatív elektrosztatikus potenciál jelenlétét demonstrálva. ${ }^{34}$

A hisztidin, a fenilalanin és a tirozin ammónia-liázok (HAL, PAL és TAL) mindegyike katalizálja az ammónia eliminációját a post-transzlációs elektrofil prosztetikus csoportjuk (MIO) segítségével. ${ }^{35-37}$ Két egymástól eltérő magyarázat született a reakció mechanizmusának magyarázatára az $N$-MIO illetve a Friedel-Crafts (FC) típusú intermediert feltételezve. Mindkét magyarázat közös pontja egy kovalens intermedier képződése. Ez a zárt szerkezetü aktív centrumban lehetővé tesz egy szisztematikus konformációs analízist. QM/MM módszerrel végzett összehasonlító elemzés segítségével kimutattuk, hogy a TAL enzim esetén a lehetséges kovalens intermedierek vonatkozásában az $N$-MIO intermedier energiája kb. 140 $\mathrm{kcal} /$ mol-lal alacsonyabb, mint a jobb FC állapoté. ${ }^{4,38} \mathrm{~A}$ kapott eredmények teljesen összevágnak a PcPAL szerkezetén végzett ligandum dokkolási és konformációs analízis számításokkal. ${ }^{39}$ Kutatásaink során elöször mutattunk rá a Tyr300-nak protonátadással játszott kettős (a szubsztrát nukleofilicitását és a MIO elektrofilicitását növelő) szerepére. A számított reakcióséma második átmeneti állapota egy összehangolt $\mathrm{C}-\mathrm{N}$ kötéshasadást mutat az $N$-MIO intermedier és a Tyr60 által deprotonált pro- $S \beta$ pozició között. Sikerült megmagyarázni az enzim bázikus centrumainak (Tyr60 és Tyr300) valamint a többi katalitikus rész (Asn203, Arg303, Asn333 és Asn435) szerepét is, melyek azonos módon megtalálhatóak az összes ismert MIO tartalmú ammónia liáz és 2,3-aminomutáz aminosav- szekvenciájában és 3D szerkezetében.

PAL enzimet mágneses nanorészecskére rögzítve, majd mikrofliudukai reaktorba töltve in-line UV detektor alkalmazásával kísérletileg sikerült alátámasztani, hogy az enzim katalizálja az ammónia eliminációját az aciklusos propargilglicin (PG) esetében az ammónium (E)-pent-2-én-4-inoátot eredményezve. Ez a tény kizárja az FC-típusú átmenet lehetőségét. A reakció megfordításával kizárólag az L-PG terméket nyertük, ami szintén kizárja a feltételezett nagyon exoterm egylépéses mechanizmust ( 9. ábra). A QM/MM számítások alátámasztották, hogy mind az L-PG-ből, mind az L-Phe-ból származó N-MIO intermedierek hasonló elrendezést mutatnak az aktív centrumon belül, ami egyértelmüen alátámasztja az $N-\mathrm{MIO}$ mechanizmust. ${ }^{40}$ 


$$
\overbrace{{ }_{\mathrm{NH}_{3}}}^{\mathrm{CO}_{2}^{\ominus}}
$$

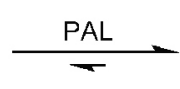

DL-propargilglicin

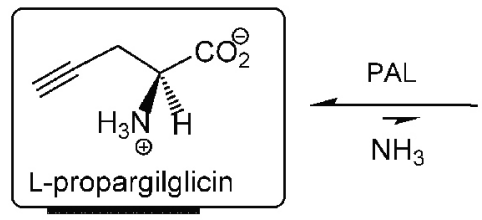

ammónium
(E)-pent-2-én-4-inoát

9. Ábra. Propargilglicin reakciója PAL enzimmel

A MIO enzimek szerkezetvizsgálatában szerzett számítógépes tapasztalat segítségével megterveztük a PcPAL enzim mutáns változatát. Az aromás kötőhelyért felelös F137-es aminosavat kisebb, hidrofób aminosavakra cserélve azt vélelmeztük, hogy az enzim jobban elfogadja a sztirilalanint szubsztrátjának. A megtervezett mutánsokat elóállítva és tesztelve megállapítottuk, hogy a valin aminosavat tartalmazó mutáns mind a sztirilalanin, mind az $o$-Cl, $p$-Cl és $p-\mathrm{NO}_{2}$ származéka esetében hatékonynak bizonyult. Sajnálatos módon azonban a fordított reakció (ammónia addíció) mind a vad-törzs, mind a mutánsok esetében sikertelen volt. ${ }^{5}$

\section{Hivatkozások}

1. Poppe, L.; Novák, L.; Selective Biocatalysis: A Synthetic Approach, Verlag Chemie, Weinheim-New York, 1992.

2. Poppe, L.; Nagy, J.; Hornyánszky, G.; Boros, Z. Sztereoszelektív szintézisek (in Hungarian), Typotex, Budapest, 2011. https://doi:10.13140/RG.2.1.3824.7526 Poppe, L.; Nagy, J.; Hornyánszky, G.; Boros, Z (Poppe, L.; Nográdi, M.; EDS.): Stereochemistry and Stereoselective Synthesis - An Introduction, Weinheim-New York: Wiley-VCH Verlag KGaA, 2016.

3. Boros, Z.; Hornyánszky, G.; Nagy, J.; Poppe, L. "Stereoselective hydrolase-catalyzed processes in continuous-flow mode", in Cascade Biocatalysis: Stereoselective and Environmentally Friendly Reactions (Riva S, Fessner W, Eds.), Wiley-VCH, Weinheim, 2014, 1999-230. https://doi.org/10.1002/9783527682492.ch9

4. Pilbák, S.; Farkas, Ö.; Poppe, L. Chem Eur J, 2012, 18, 7793-7802. https://doi.org/10.1002/chem.201103662

5. Bencze, L. C.; Filip, A.; Bánóczi, G.; To?a, M. I.; Irimie, F.-D.; Gellért, Á.; Poppe, L.; Paizs, C,Org. Biomol. Chem. 2017, 15, 3717-3727. https://doi.org/10.1039/C7OB00562H

6. Boros, Z.; Abaháziová, E.; Oláh, M.; Sátorhelyi, P.; Erdélyi, B.; Poppe, L. Chim. Oggi, 2012, 30(5), 26-29.

7. Nagy-Győr, L.; Boros, Z.; Poppe, L. Per. Polytechn. Chem. Eng. 2013, 57(1-2), 37-40.

https://doi.org/10.3311/PPch.2168

8. Boros Z.; Weiser, D.; Márkus, M.; Abaháziová, E.; Magyar, Á., Tomin, A.; Koczka, B.; Kovács, P.; Poppe, L. Proc. Biochem., 2013, 48(7), 1039-1047. https://doi.org/10.1016/j.procbio.2013.05.002

9. Abaházi, E.; Lestál, D.; Boros, Z.; Poppe, L. Molecules 2016, 21, 767. https://doi.org/10.3390/molecules21060767

\section{3. Összegzés és kitekintés}

A Bioorganikus Kémiai Kutatócsoport által kutatott területek (kemoenzimatikus módszerekkel megvalósított új sztereoszelektív szintézisek, a biotranszformációk hatásának fokozása új enzim immobilizálási technikák kifejlesztésével és folytonos átfolyásos rendszerek alkalmazásával, enzimek szerkezetének és hatásmechanizmusának tanulmányozása elméleti számítások és gyakorlati megvalósítások segítségével) hozzájárulnak új, hatékony és környezetbarát szintetikus módszerek kifejlesztéséhez. Ezek az összetett kutatási erőfeszítések elősegíthetik a modern, biotechnológiával integrált szintetikus módszerek fejlesztését és felhasználását akár humán területeken is. A szerkezetvizsgálatban szerzett számítógépes tapasztalat segítségével elérhetővé vált a célzott, adott szubsztrátra szabott mutáns enzimek megtervezése is.

\section{Köszönetnyilvánítás}

A szerzők köszönetet mondanak az OTKA (NN-103242), a Nemzeti Fejlesztési Ügynökség (NKFP 07 A2 FLOWREAC), az Új Magyarország Fejlesztési Terv (TÁMOP-4.2.2.B-10/1-2010-0009), A Magyar Kutatási és Innovációs Alap (KMR 12-1-2012-0051 és KMR 12-1-2012-0140), és az EU COST (Action CM0701 és CM1303) projektek támogatásáért.

10. Tomin, A.; Weiser, D.; Bata, Z.; Corici, L.; Péter, F.; Poppe, L. Stud. Univ. Babes-Bolyai Chem. 2009, 54(Sp 2), 77-82. http://mycite.omikk.bme.hu/doc/97971.pdf

11. Weiser, D.; Tomin, A.; Poppe, L. Stud. Univ. Babes-Bolyai Chem. 2010, 55(4), 283-288.

http://mycite.omikk.bme.hu/doc/103009.pdf

12. Tomin, A.; Weiser, D.; Hellner, G.; Bata, Z.; Corici, L.; Péter, F.; Koczka, B.; Poppe, L. Proc. Biochem., 2011, 46, 52-58. https://doi.org/10.1016/j.procbio.2010.07.021

13. Hellner, G.; Boros, Z.; Tomin, A.; Poppe, L. Adv. Synth. Catal., 2011, 353, 2481-2491. https://doi.org/10.1002/adsc.201100329

14. Weiser, D.; Boros, Z.; Hornyánszky, G.; Tóth, A.; Poppe L. Proc. Biochem. 2012, 47, 428-434. https://doi.org/10.1016/j.procbio.2011.11.023

15. Weiser, D.; Sóti, P. L.; Bánóczi, G.; Bódai, V.; Kiss, B.; Gellért, Á.; Nagy, Z. K.; Koczka, B.; Szilágyi, A.; Marosi, G.; Poppe, L. Tetrahedron 2016, 72(46), 7335-7342. https://doi.org/10.1016/j.tet.2016.06.027

16. Weiser, D.; Varga, A.; Kovács, K.; Nagy, F.; Szilágyi, A.; Vértessy, B. G.; Paizs, C.; Poppe, L. ChemCatChem 2014, 6(4), 1463-1469. https://doi.org/10.1002/cctc.201300806

17. Ösze, M.; Weiser, D.; Hornyánszky, G.; Poppe, L. Stud. Univ. Babes-Bolyai Chem. 2012, 57(2), 129-137.

18. Szigeti, M.; Töke, E. R.; Turóczi, M. C.; Nagy, V.; Szakács, G.; Poppe, L. ARKIVOC, 2008, (3), 54-65. http://mycite.omikk.bme.hu/doc/54061.pdf

19. Toşa, M.; Pilbák, S.; Moldovan, P.; Paizs, C.; Szatzker, G.; Szakács, G.; Novák, L.; Irimie, F.-D.; Poppe, L. Tetrahedron: Asymmetry, 2008, 19, 1844-1852. https://doi.org/10.1016/j.tetasy.2008.07.004 
20. Brem, J.; Pilbák, S.; Paizs, C.; Bánóczi, G.; Irimie, F.-D.; Toşa, M.-I.; Poppe, L. Tetrahedron:Asymmetry, 2011, 22(8), 916-923. https://doi.org/10.1016/j.tetasy.2011.05.009

21. Brem, J.; Naghi, M.; Toşa, M. I.; Boros, Z.; Poppe, L.; Irimie, F. D.; Paizs, C. Tetrahedron: Asymmetry, 2011, 22, 1672-1679. https://doi.org/10.1016/j.tetasy.2011.09.005

22. Varga, A.; Zaharia, V.; Nógrádi, M.; Poppe, L. Tetrahedron: Asymmetry 2013, 24, 1389-1394. https://doi.org/10.1016/j.tetasy.2013.09.007

23. Csuka, P.; Boros, Z.; Örfi, L.; Dobos, J.; Poppe, L.; Hornyánszky, G. Tetrahedron: Asymmetry 2015, 26, 644-649. https://doi.org/10.1016/j.tetasy.2015.04.013

24. Oláh, M.; Boros, Z.; Hornyánszky, G.; Poppe, L. Tetrahedron 2016, 72(46), 7249-7255. https://doi.org/10.1016/j.tet.2015.12.046

25. Bartha-Vári, J. H.; Toşa, M. I.; Irimie, F.-D.; Weiser, D.; Boros, Z.; Vértessy, B. G.; Paizs, C.; Poppe, L. ChemCatChem 2015, 7(7), 1122-1128. https://doi.org/10.1002/cctc.201402894

26. Bódai, V.; Nagy-Győr, L.; Örkényi, R.; Molnár, Z.; Kohári, S.; Erdélyi, B.; Nagymáté, Z.; Romsics, C.; Paizs, C.; Poppe, L.; Hornyánszky, G. J. Mol. Catal. B Enzym. 2016, 134A, 206-214. https://doi.org/10.1016/j.molcatb.2016.11.003

27. Boros, Z.; Szigeti, M.; Tomin, A.; Kovács, P; Ürge, L.; Darvas, F.; Poppe, L. Stud. Univ. Babes-Bolyai Chem. 2009, 54(Sp 2), 69-75. http://mycite.omikk.bme.hu/doc/97970.pdf

28. Csajági,Cs.; Szatzker, G.; Tőke, E. R.; Ürge, L.; Darvas, F.; Poppe, L. Tetrahedron:Asymmetry, 2008, 19, 237-246. https://doi.org/10.1016/j.tetasy.2008.01.002

29. Tomin, A.; Hornyánszky, G.; Kupai, K.; Dorkó, Z.; Ürge, L.; Darvas, F.; Poppe, L. Proc. Biochem., 2010, 45, 859-865. https://doi.org/10.1016/j.procbio.2010.02.006

30. Boros, Z.; Falus, P.; Márkus M.; Weiser D.; Oláh M.; Hornyánszky G.; Nagy J.; Poppe L. J. Mol. Catal. B, Enzym. 2013, 85-86, 119-125. https://doi.org/10.1016/j.molcatb.2012.09.004
31. Falus, P.; Boros, Z.; Hornyánszky, G.; Nagy, J.; Darvas, F.; Ürge, L.; Poppe, L. Stud. Univ. Babes-Bolyai Chem. 2010, 55(4), 289-298. http://mycite.omikk.bme.hu/doc/103010.pdf

32. Falus, P.; Boros, Z.; Hornyánszky, G.; Nagy, J.; Darvas, F.; Ürge, L.; Poppe, L.:.Tetrahedron Lett., 2011, 52, 1310-1312. https://doi.org/10.1016/j.tetlet.2011.01.062

33. Pilbák, S.; Tomin, A.; Rétey, J.; Poppe, L. FEBS J. 2006, 273(5), 1004-1019. https://doi.org/10.1111/j.1742-4658.2006.05127.x

34. Kovács, K.; Bánóczi, G.; Varga, A.; Szabó, I.; Holczinger, A.; Hornyánszky, G.; Zagyva, I.; Paizs, C.; Vértessy, B. G.; Poppe, L. PLoS ONE 2014, 9(1), e85943. https://doi.org/10.1371/journal.pone.0085943

35. Poppe. L. Curr. Opin. Chem. Biol., 2001, 5, 512-524. https://doi.org/10.1016/S1367-5931(00)00253-2

36. Poppe, L.; Rétey, J. Angew. Chem., 2005, 117, 3734-3755; Angew. Chem., Int. Ed. Engl., 2005, 44, 3668-3688. https://doi.org/10.1002/anie.200461377

37. Poppe, L.; Paizs, C.; Kovács, K.; Irimie, F.-D.; Vértessy, B. "Preparation of unnatural amino acids with ammonia-lyases and 2,3-aminomutases", in Methods in Molecular Biology, Vol. 794 "Unnatural amino acids", Part 1; New York: Springer Science+Business Media, 2012, pp 3-19. https://doi.org/10.1007/978-1-61779-331-8_1

38. Poppe, L.; Pilbák, S.; Paizs, C.; Rétey, J. Stud. Univ. Babes-Bolyai Chem. 2008, 53(2), 15-19. http://mycite.omikk.bme.hu/doc/66210.pdf

39. Seff, A. L.; Pilbák, S.; Poppe, L. Stud. Univ. Babes-Bolyai Chem. 2008, 53(2), 67-71. http://mycite.omikk.bme.hu/doc/66209.pdf

40. Weiser, D.; Bencze L. C.; Bánóczi, G.; Ender, F.; Kókai, E.; Szilágyi, A.; Vértessy, B. G.; Farkas, Ö; Paizs, C.; Poppe, L. ChemBioChem 2015, 16(16), 2283-2288. https://doi.org/10.1002/cbic.201500444

\section{From synthetic chemistry to enzyme engineering - Introduction of the Bioorganic Chemistry Group}

The Bioorganic Chemistry Research Group was established in 2005 at the Department of Organic Chemistry and Technology, Budapest University of Technology and Economics by Prof. László Poppe . Furthermore, two senior scientist, one postdoctoral fellow, $11 \mathrm{PhD}$ students and 30-40 undergraduate students contribute to our research results. At BME about $220 \mathrm{~m}^{2}$ well-equipped laboratory space is available for bioorganic chemistry research (with equipment for synthetic, biotransformation and basic protein works; 2 HPLC's, 3 GC's, 3 UV-VIS, FTIR, gelelectrophoresis, bench-top centrifuges, pumps and continuous-flow reactors). In addition, high performance PC's and molecular modeling program packages are available for protein modelling and QM/MM investigations.

The activity of Bioorganic Chemistry Group (BCG) covers a wide range of topics from development of novel synthetic methods, mostly using biocatalysis ${ }^{1}$ for stereoselective synthesis $^{2}$ via novel enzyme immobilization methods and stereoselective hydrolase-catalyzed processes $^{3}$ in continuous-flow mode to sophisticated QM/MM calculations for exploring enzyme mechanisms. ${ }^{4,5}$ The most studied enzymes by BCG are lipases and the so-called MIO enzymes.
One of BCG's major interest is to develop novel forms of immobilized enzymes and to perform kinetic resolutions or enantiotope selective biotransformations with them, preferably in continuous-flow mode (Fig. 1). The FLOWREAC project allowed us to utilize the continuous-flow technology of ThalesNano and gain expertise in enzyme-immobilization (Fig. 1B and 1C) and in development of continuous-flow biotransformations (Fig. $1 \mathrm{C}$ and 1D).

Enzyme immobilization on a solid support is one of the methods to use enzymes in industry because it confers easy product separation and enhanced thermal and $\mathrm{pH}$ stability. Ideal properties for immobilization support include chemical and mechanical stability, hydrophilicity, inertness toward enzymes, ease of derivatization, biocompatibility, resistance to microbial attack, and a large surface area. Among the many organic and inorganic supports our group focused mostly on mesoporous silica materials (MPs) for use in enzyme immobilization. ${ }^{6-8}$ MPs have large surface areas with relatively large-pore diameters $(5-100 \mathrm{~nm})$ that match the sizes of the enzymes. 
Entrapment is a useful technique of enzyme immobilization. The sol-gel encapsulation of lipases proved to be a particularly easy and effective way to enhance the mechanical and catalytic properties of biocatalysts. The sol-gel encapsulated enzymes usually retain their selectivity whereas their heat stability or specific activity may be significantly improved. BCG researchers investigated the lipase immobilization by entrapment in sol-gel matrices to study the effect of enzymes, supports, enzyme/support ratios, silane precursor composition and bioimprinting effect of additives. ${ }^{10-14}$ In addition to test the resulting sol-gel lipases in kinetic resolution of 1-phenylethanol using batch mode, the reactions were studied in continuous-flow systems as well. ${ }^{8}$

BCG demonstrated for the first time that the inexpensive glycerol diglycidyl ether (GDE) could be used conveniently as a bis-epoxide type cross-linking agent in preparation of cross-linked enzyme aggregates (CLEAs) from two different enzyme classes (Fig. 4). ${ }^{16}$

A number of multi-ton industrial processes use enzymatic kinetic resolution, often with lipases that tolerate different substrates. This initiated the activity of BCG to develop novel kinetic resolution (KR) and dynamic kinetic resolution (DKR) processes (Fig. 5 and Fig. 6). Because efficient screening methods has increasing significance in rapid evaluation of novel biocatalysts BCG developed a multi-substrate kinetic resolution screening method for lipase biocatalysts based on enantioselective GC method. ${ }^{17}$
Stereoselective biotransformations - such as asymmetric biotransformation, kinetic resolution and dynamic kinetic resolution - developed by BCG enabling the continuous-mode hydrolase-mediated production of compounds in high enantiomeric purity are discussed (Fig 8).

Besides recombinant production and experimental biochemical studies on PAL, ${ }^{35,36}$ BCG researchers performed theoretical calculations such as homology modeling, docking, molecular dynamics and QM/MM calculation on the MIO-enzymes. A detailed QM/MM study on the mechanism of the TAL reaction revealed the $N$-MIO intermediate as the most plausible for the TAL reaction. ${ }^{4} \mathrm{We}$ explored for the first time the role of Tyr300 in a tandem nucleophilic and electrophilic enhancement by a proton transfer.

The synergy and integration between various research interests of BCG involving novel stereoselective synthetic methods by chemoenzymatic techniques, intensification of biotransformations by novel immobilization methods of various enzymes and by continuous-flow reactions together with enzyme structural and mechanistic studies by experimental and computational techniques can result in novel, effective and ecofriendly synthetic methods. Thus, the complex research efforts of BCG can have positive impact on the development modern, integrated synthetic methods, or even on human applications of the biocatalysts. 